\title{
Association of prestroke metformin use, stroke severity, and thrombolysis outcome
}

\begin{abstract}
Westphal, Laura P ; Widmer, Roni ; Held, Ulrike ; Steigmiller, Klaus ; Hametner, Christian ; Ringleb, Peter ; Curtze, Sami ; Martinez-Majander, Nicolas ; Tiainen, Marjaana ; Nolte, Christian H ; Scheitz, Jan F ; Erdur, Hebun ; Polymeris, Alexandros A ; Traenka, Christopher ; Eskandari, Ashraf ; Michel, Patrik ; Heldner, Mirjam R ; Arnold, Marcel ; Zini, Andrea ; Vandelli, Laura ; Coutinho, Jonathan M ; Groot, Adrien E ; Padjen, Visnja ; Jovanovic, Dejana R ; Bejot, Yannick ; Brenière, Céline ; Turc, Guillaume ; Seners, Pierre ; Pezzini, Alessandro ; Magoni, Mauro ; Gensicke, Henrik ; Nederkoorn, Paul ; Luft, Andreas Rüdiger ; Leys, Didier ; Tatlisumak, Turgut ; Kägi, Georg ; Scherrer, Michael J ; Gilliot, Sixtine ; Engelter, Stefan T ; Wegener, Susanne
\end{abstract}

\begin{abstract}
OBJECTIVE To evaluate whether pretreatment with metformin (MET) is associated with less stroke severity and better outcome after IV thrombolysis (IVT), we analyzed a cohort of 1,919 patients with stroke with type 2 diabetes mellitus in a multicenter exploratory analysis. METHODS Data from patients with diabetes and ischemic stroke treated with IVT were collected within the European Thrombolysis in Ischemic Stroke Patients (TRISP) collaboration. We applied propensity score matching (PSM) to obtain balanced baseline characteristics of patients treated with and without MET. RESULTS Of 1,919 patients with stroke with type 2 diabetes who underwent IVT, 757 (39\%) had received MET before stroke (MET+), whereas 1,162 (61\%) had not (MET-). MET+ patients were younger with a male preponderance. Hypercholesterolemia and pretreatment with statins, antiplatelets, or antihypertensives were more common in the MET+ group. After PSM, the 2 groups were well balanced with respect to demographic and clinical aspects. Stroke severity on admission (NIH Stroke Scale $10.0 \pm 6.7$ vs $11.3 \pm$ 6.5), 3-month degree of independence on modified Rankin Scale (2 [interquartile range (IQR) 1.0-4.0] vs 3 [IQR 1.0-4.0]), as well as mortality (12.5\% vs $18 \%)$ were significantly lower in the MET+ group. The frequency of symptomatic intracerebral hemorrhages did not differ between groups. HbA1c levels were well-balanced between the groups. CONCLUSIONS Patients with stroke and diabetes on treatment with MET receiving IVT had less severe strokes on admission and a better functional outcome at 3 months. This suggests a protective effect of MET resulting in less severe strokes as well as beneficial thrombolysis outcome.
\end{abstract}

DOI: https://doi.org/10.1212/WNL.0000000000009951

Posted at the Zurich Open Repository and Archive, University of Zurich

ZORA URL: https://doi.org/10.5167/uzh-190295

Journal Article

Published Version

Originally published at:

Westphal, Laura P; Widmer, Roni; Held, Ulrike; Steigmiller, Klaus; Hametner, Christian; Ringleb, Peter; Curtze, Sami; Martinez-Majander, Nicolas; Tiainen, Marjaana; Nolte, Christian H; Scheitz, Jan 
F; Erdur, Hebun; Polymeris, Alexandros A; Traenka, Christopher; Eskandari, Ashraf; Michel, Patrik; Heldner, Mirjam R; Arnold, Marcel; Zini, Andrea; Vandelli, Laura; Coutinho, Jonathan M; Groot, Adrien E; Padjen, Visnja; Jovanovic, Dejana R; Bejot, Yannick; Brenière, Céline; Turc, Guillaume; Seners, Pierre; Pezzini, Alessandro; Magoni, Mauro; Gensicke, Henrik; Nederkoorn, Paul; Luft, Andreas Rüdiger; Leys, Didier; Tatlisumak, Turgut; Kägi, Georg; Scherrer, Michael J; Gilliot, Sixtine; Engelter, Stefan T; Wegener, Susanne (2020). Association of prestroke metformin use, stroke severity, and thrombolysis outcome. Neurology, 95(4):e362-e373.

DOI: https://doi.org/10.1212/WNL.0000000000009951 


\section{Association of prestroke metformin use, stroke severity, and thrombolysis outcome}

\author{
Laura P. Westphal, MD, Roni Widmer, MMed, Ulrike Held, PhD, Klaus Steigmiller, BSc, Christian Hametner, MD, \\ Peter Ringleb, MD, Sami Curtze, MD, PhD, Nicolas Martinez-Majander, MD, Marjaana Tiainen, MD, \\ Christian H. Nolte, MD, Jan F. Scheitz, MD, Hebun Erdur, MD, Alexandros A. Polymeris, MD, \\ Christopher Traenka, MD, Ashraf Eskandari, RN, Patrik Michel, MD, Mirjam R. Heldner, MD, \\ Marcel Arnold, MD, Andrea Zini, MD, Laura Vandelli, MD, Jonathan M. Coutinho, MD, Adrien E. Groot, MD, \\ Visnja Padjen, MD, PhD, Dejana R. Jovanovic, MD, Yannick Bejot, MD, PhD, Céline Brenière, MD, \\ Guillaume Turc, MD, PhD, Pierre Seners, MD, PhD, Alessandro Pezzini, MD, Mauro Magoni, MD, \\ Didier Leys, MD, Sixtine Gilliot, MD, Michael J. Scherrer, MD, Georg Kägi, MD, Andreas R. Luft, MD, \\ Henrik Gensicke, MD, Paul Nederkoorn, MD, Turgut Tatlisumak, MD, PhD, Stefan T. Engelter, MD, * and \\ Susanne Wegener, MD, * for the Thrombolysis in Ischemic Stroke Patients (TRISP) Study Group
}

Neurology ${ }^{\circledR}$ 2020;95:e362-e373. doi:10.1212/WNL.0000000000009951

\section{Abstract}

\section{Objective}

To evaluate whether pretreatment with metformin (MET) is associated with less stroke severity and better outcome after IV thrombolysis (IVT), we analyzed a cohort of 1,919 patients with stroke with type 2 diabetes mellitus in a multicenter exploratory analysis.

\section{Methods}

Data from patients with diabetes and ischemic stroke treated with IVT were collected within the European Thrombolysis in Ischemic Stroke Patients (TRISP) collaboration. We applied propensity score matching (PSM) to obtain balanced baseline characteristics of patients treated with and without MET.

\section{Results}

Of 1,919 patients with stroke with type 2 diabetes who underwent IVT, 757 (39\%) had received MET before stroke (MET+), whereas 1,162 (61\%) had not (MET-). MET+ patients were younger with a male preponderance. Hypercholesterolemia and pretreatment with statins, antiplatelets, or antihypertensives were more common in the MET+ group. After PSM, the 2 groups were well balanced with respect to demographic and clinical aspects. Stroke severity on admission (NIH Stroke Scale $10.0 \pm 6.7$ vs $11.3 \pm$ 6.5), 3-month degree of independence on modified Rankin Scale (2 [interquartile range (IQR) 1.0-4.0] vs 3 [IQR $1.0-4.0])$, as well as mortality $(12.5 \%$ vs $18 \%)$ were significantly lower in the MET+ group. The frequency of symptomatic intracerebral hemorrhages did not differ between groups. HbAlc levels were well-balanced between the groups.

\section{Conclusions}

Patients with stroke and diabetes on treatment with MET receiving IVT had less severe strokes on admission and a better functional outcome at 3 months. This suggests a protective effect of MET resulting in less severe strokes as well as beneficial thrombolysis outcome.

\author{
Correspondence \\ Dr. Wegener \\ Susanne.Wegener@usz.ch
}

\footnotetext{
*These authors contributed equally to this work as co-last authors.

From the Department of Neurology (L.P.W., R.W., A.R.L., S.W.), University Hospital Zurich; Epidemiology, Biostatistics and Prevention Institute, Department of Biostatistics (U.H., K.S.), University of Zurich, Switzerland; Department of Neurology (C.H., P.R.), University Hospital Heidelberg, Germany; Department of Neurology (S.C., N.M.-M., M.T.), University of Helsinki and Helsinki University Hospital, Finland; Department of Neurology and Center for Stroke Research (C.H.N., J.F.S., H.E.), Charité University Hospital, Berlin, Germany; Stroke Center and Neurology (A.A.P., C.T., H.G., S.T.E.), University Hospital Basel and University Basel; Department of Neurology (A.E., P.M.), University Hospital Lausanne; Department of Neurology (M.R.H., M.A.), Inselspital, Bern University Hospital, University of Bern, Switzerland; Department of Neurology and Stroke Center (A.Z.), IRCCS Istituto delle Scienze Neurologiche di Bologna, Maggiore Hospital; Stroke Unit (L.V.), Department of Neuroscience, S'Agostino-Estense Hospital, Modena University Hospital, Italy; Department of Neurology (J.M.C., A.E.G., P.N.), Amsterdam University Medical Centers (AUMC), Location AMC, University of Amsterdam, the Netherlands; Neurology Clinic Belgrade (V.P., D.R.J.), Clinical Centre of Serbia; Medical Faculty (D.R.J.), University of Belgrade, Serbia; Department of Neurology (Y.B., C.B.), University Hospital of Dijon, University of Burgundy; Department of Neurology (G.T., P.S.), Sainte-Anne Hospital, Paris, France; Department of Clinical and Experimental Sciences (A.P.), Neurology Clinic, University of Brescia; Stroke Unit (M.M.), ASST Spedali Civili, Brescia, Italy; Department of Neurology (D.L., S.G.), University Hospital of Lille, France; Department of Neurology (M.J.S., G.K.), St. Gallen Cantonal Hospital, Switzerland; Department of Neurology (T.T.), Sahlgrenska University Hospital; Department of Clinical Neurosciences (T.T.), Institute of Neuroscience and Physiology, Sahlgrenska Academy at University of Gothenburg, Sweden; and Neurorehabilitation Unit (S.T.E.), University Center for Medicine of Aging and Rehabilitation Basel, Felix Platter Hospital, University of Basel, Switzerland.

Go to Neurology.org/N for full disclosures. Funding information and disclosures deemed relevant by the authors, if any, are provided at the end of the article.

For the Thrombolysis in Ischemic Stroke Patients (TRISP) Study Group coinvestigators are listed in the appendix 2 at the end of the article.
} 


\section{Glossary}

AMPK $=5^{\prime}$ adenosine monophosphate-activated protein kinase; $\mathbf{C I}=$ confidence interval; $\mathbf{I N R}=$ international normalized ratio; IVT = IV thrombolysis; MET = metformin; $\mathbf{m R S}=$ modified Rankin Scale; NIHSS = NIH Stroke Scale; OR = odds ratio; PSM = propensity score matching; TOAST = Trial of Org 10172 in Acute Stroke Treatment; TRISP = Thrombolysis in Ischemic Stroke Patients; $\mathbf{s I C H}=$ symptomatic intracranial hemorrhage; SMD = standardized mean difference.

Diabetes mellitus is a known risk factor for stroke and associated with a higher rate of complications after thrombolysis as well as less favorable clinical outcome. ${ }^{1}$ Around $15 \%$ of patients with ischemic stroke eligible for thrombolysis have type 2 diabetes mellitus. ${ }^{2}$ Due to demographic changes as well as unfavorable lifestyle factors in industrialized countries, the incidence of type 2 diabetes mellitus is rising. ${ }^{3}$

For treatment of type 2 diabetes, metformin (MET) is available as an oral antidiabetic prodrug of the biguanide class and widely used as first-line treatment in addition to lifestyle modifications. ${ }^{4}$ MET reduces hepatic glucose production and intestinal glucose resorption and increases glucose uptake into muscle tissue. In addition to its antidiabetic properties, MET has been suggested to exert beneficial effects in cardiovascular disease by maintaining glycemic control without hypoglycemia, improving lipoprotein metabolism, and protecting endothelial/ vascular function. ${ }^{5,6}$ Experimental stroke data suggest neuroprotective effects of chronic MET treatment, possibly through modification of $5^{\prime}$ adenosine monophosphate-activated protein kinase (AMPK) activity, an enzyme involved in cellular energy regulation. ${ }^{7}$

Motivated by the experimental evidence suggesting cardiovascular protection afforded by MET and the fact that a relevant number of patients with stroke have diabetes, the aim of this multicenter study was to evaluate whether pretreatment with MET affects initial stroke severity and results in better outcomes of thrombolysis in patients with acute ischemic stroke with type 2 diabetes mellitus.

\section{Methods}

\section{Study design and study population}

For this multicenter retrospective analysis, as a joint initiative of 15 stroke centers within the European Thrombolysis in Ischemic Stroke Patients (TRISP) collaboration, data were collected from patients with acute ischemic stroke treated with IV thrombolysis (IVT) without endovascular treatment. ${ }^{8}$ The participating institutions were stroke centers according to national criteria or criteria of the European Stroke Organisation. ${ }^{9}$

\section{Standard protocol approvals, registrations, and patient consents}

The ethics committee in Zurich, Switzerland (KEK-ZH: 2014-0304) approved the study. Additional local ethical approval differed across centers and was obtained if required.

\section{Data collection}

Data for all patients were collected using a standardized form with predefined variables as described previously. ${ }^{10,11}$ Local TRISP investigators completed the form systematically and retrospectively using data from prospectively composed inhospital thrombolysis registries, as done previously. ${ }^{11} \mathrm{Com}-$ pleted forms with encrypted data from all centers were sent to the coordinating center in Zurich for merging and analysis. Only data from patients diagnosed with type 2 diabetes mellitus before stroke or at the time of stroke based on admission $\mathrm{HbAlc}$ values $\geq 6.5 \%$ were included. ${ }^{12,13}$

\section{Baseline data analysis}

For baseline data analysis, the following prospectively ascertained variables with predefined definitions ${ }^{10}$ were used: age, sex, hypertension, hypercholesterolemia, coronary heart disease, atrial fibrillation, current smoking, prior stroke, prestroke medication (antihypertensives, statins, antiplatelets, anticoagulants, including the use vs nonuse of MET), clinical (stroke-to-needle time) and laboratory findings (admission blood pressure, platelets, glucose, creatinine, international normalized ratio [INR]), and stroke etiology according to the Trial of Org 10172 in Acute Stroke Treatment (TOAST) criteria. $^{14}$ Stroke-to-needle time was defined by the interval between first symptom onset and the application of IVT. In case information about antidiabetic treatment was not part of the thrombolysis registry, this information was obtained from patient charts.

\section{Outcome measures}

The objective of our study was to address the influence of MET on primary and secondary outcomes. These were the modified Rankin Scale (mRS) for 3-month functional impairment and admission NIH Stroke Scale (NIHSS) for stroke severity as primary outcomes. Secondary outcome measures were mortality (all causes) within 3 months of stroke and symptomatic intracranial hemorrhage $(\mathrm{sICH})$ according to the European Cooperative Acute Stroke Study II criteria. ${ }^{15}$

\section{Sample size considerations}

The number of confounders in this study was 19; together with the treatment group (MET+/MET-), 20 independent variables resulted. Without variable selection procedures, one can assume that 10 observations (continuous outcome) or 10 events (binary outcome) per independent variable are sufficient to estimate an adjusted treatment effect of MET. For a binary outcome, e.g., mortality within 3 months of stroke, with an anticipated prevalence of between $10 \%$ and 15\%, 10 events per variable would result in 1,334-2,000 patients to include. 


\section{Descriptive statistics}

Descriptive statistics include mean and SD for continuous variables, median and interquartile range for ordinal variables, and number and percentage of total for categorical variables. These were compared between MET treatment groups using the independent samples Wilcoxon test for continuous variables or $\chi^{2}$ test for categorical variables. Balancing of baseline characteristics before and after matching was assessed with the absolute standardized mean difference for continuous variables and the absolute mean difference for categorical variables, both abbreviated SMD.

\section{Propensity score matching and multiple imputation}

We used a propensity score matching (PSM) approach to balance baseline characteristics between the treatment groups. The propensity score was the probability of receiving metformin (MET+), and was estimated from a logistic regression model including variables potentially influencing the treatment group and the defined outcome measures. Patients with missing outcome variables or unspecified MET status were excluded from the analysis. Variables in the PSM were selected based on previous studies and judgment of the investigators (L.P.W., S.W.), namely age, sex, hypertension, hypercholesterolemia, coronary heart disease, atrial fibrillation, current smoking, prior stroke, prior treatment with antihypertensives, statins, antiplatelets, anticoagulants, blood pressure on admission (systolic and diastolic), glucose, creatinine, platelets, INR on admission, and stroke etiology. Missing values were age (0\%), sex (0\%), hypertension (0\%), hypercholesterolemia $(0.5 \%)$, coronary heart disease $(0.2 \%)$, atrial fibrillation (0.7\%), current smoking (20.8\%), prior stroke $(0.4 \%)$, prior treatment with antihypertensives $(27.3 \%)$, statins $(5.6 \%)$, antiplatelets (1\%) or anticoagulants (0.9\%), blood pressure on admission (systolic $7 \%$ and diastolic $7.1 \%)$, glucose $(3.7 \%)$, creatinine $(3.4 \%)$, platelets (17.8\%), INR on admission (29.7\%), as well as stroke etiology according to the TOAST criteria (1.7\%).

For covariates with missing values, multiple imputation using chained equations assuming missingness at random in combination with PSM was carried out, following a recently published approach by Mitra and Reiter. ${ }^{16}$ In brief, 100-fold multiple imputation was applied to the data set with missing values $(m=100)$. For each of these 100 datasets, a propensity score for being in the MET+ group was estimated. Then, the 100 estimated propensity scores for each patient were averaged for substantial bias reduction, resulting in a single propensity score for each patient. The described procedure was repeated 100 times, in order to increase precision $(r=100)$. PSM was performed using an "optimal" algorithm aiming to find the samples with the smallest average absolute distance across all the matched pairs. Program code will be made available upon request by the authors. Balancing of baseline characteristics after matching was again assessed with the SMD. Covariates with an SMD $<0.1$ were considered balanced. ${ }^{17}$

\section{Comparison of outcomes}

To report on the raw comparison of outcomes between treatment groups, we used the Wilcoxon test for continuous and ordinal outcomes and $\chi^{2}$ tests for categorical outcomes.

Outcomes of the matched samples were compared with either McNemar tests (for categorical outcomes) or paired Wilcoxon tests (for continuous/ordinal outcomes). Specifically, a variant of the Wilcoxon test able to address ties was used. ${ }^{18}$ The paired versions were used to account for dependencies due to matching. The results from multiply imputed datasets were combined using the Rubin rule as well as a recently proposed formula for combining $p$ values based on $z$ transformation. ${ }^{19}$

Including the study center as matching variable was not feasible because it led to loss of cases in the matching process. Therefore, we addressed the potential confounding effect of study center by fitting 2-level random intercept models with study center, as well as matched case-control pairs as random intercepts, and treatment group "MET" as fixed effect. NIHSS on admission was not used for matching, as it was considered an outcome variable. Onset-to-treatment time was also not included in the model as it represents a hospital-dependent variable and both groups showed a balanced distribution. Linear mixed effects regression models were used for the continuous or ordinal outcome variables, as well as logistic regression for the binary outcomes. The resulting treatment effect of metformin was shown as $\beta$ coefficients, or odds ratios (OR), including 95\% confidence intervals (CIs). In the subgroup of patients in the MET+ group, the association between MET dose (in 1,000 mg) and outcomes was addressed with linear and logistic regression, including again random intercepts for study center.

All data analyses were conducted using R, version 3.6.0 for Windows (R-project.org/) and the packages tableone, mice, MatchIt, VIM, cobalt, ggplot2, lmer, and glmer.

The study was reported according to the STROBE (Strengthening the Reporting of Observational Studies in Epidemiology) guidelines for observational studies. ${ }^{20}$

\section{Data availability}

Anonymized data will be shared by request from any qualified investigator.

\section{Results}

\section{Study population and baseline characteristics}

Among 10,513 TRISP patients, 2,048 (19.5\%) were individuals with diabetes. Of these, 31 (1.5\%) were either diagnosed with type 1 diabetes or diabetes type was not specified $(n=25$, $1.2 \%)$, so that they were excluded from further analyses. Seventy-three patients $(3.5 \%)$ had missing values in at least one outcome variable or an unspecified MET status, and were also excluded from the analysis (figure 1). 
Of the remaining 1,919 patients, 757 (39\%) had been treated with metformin before stroke (MET+), whereas 1,162 (61\%) had not received prestroke metformin treatment (MET-). Mean age was 71 years in the MET+ and 74 years in the MET- group (SMD 0.240). There were substantial differences in the distribution of creatinine on admission between groups before matching with lower levels in the MET+ group. MET+ patients had a male preponderance. Hypercholesterolemia and pretreatment with statins and antihypertensives were more common in the MET+ group, whereas atrial fibrillation and pretreatment with anticoagulants were more common in the MET- group. Table 1 shows descriptive statistics for the baseline covariates before and after matching, but without multiple imputation. The comparison of baseline characteristics after imputation is shown for a single randomly chosen imputed dataset in table 2. Figure 2 demonstrates SMD before and after matching for each confounder variable. Matching achieved balancing across all baseline variables $(\mathrm{SMD}<0.1)$.

\section{Outcome analysis}

Raw results for the outcomes of the unmatched data are reported in table 3. NIHSS on admission, mRS after 3 months, and mortality were lower in the MET+ group compared to MET-. The occurrence of sICH did not differ significantly.

Analysis of the outcomes for the multiply imputed and propensity score matched pairs is shown in table 3 . Mortality in the MET+ group was $12.5 \%$ (95\% CI, $10.3 \%-15.2 \%$ ), and
$18.0 \%$ (95\% CI, 15.3\%-20.9\%) in the MET- group ( $p=$ 0.008 ). The occurrence of sICH did not differ significantly between treatment groups, but mean NIHSS on admission was lower in the MET+ patients (10.0 vs $11.3 ; p<0.001)$, as was median $\mathrm{mRS}$ after 3 months (2.0 in MET+, and 3.0 in MET-; $p<0.001$ ). Figure 3 shows the distribution of $\mathrm{mRS}$ categories for the unmatched and matched cohorts in the 2 patient groups. When adjusting for study center, the results of the random intercept models after matching revealed a lower NIHSS on admission ( $-1.05 ; 95 \% \mathrm{CI},-1.72$ to -0.38$)$, a lower $\mathrm{mRS}$ at 3 months $(-0.39 ; 95 \% \mathrm{CI},-0.59$ to -0.20$)$, as well as a lower chance of dying within 3 months (OR, 0.63; 95\% CI, 0.47-0.84) in MET+ patients. No differences were found for sICH. All results can be found in supplementary table 1 at doi.org/10.5061/dryad.s087hm4.

\section{Analysis of MET doses in correlation to outcome and distribution of HbA1c levels}

In order to assess a potential dose-dependency of MET pretreatment with outcome, we analyzed the daily dose of MET (in 1,000 mg) before stroke, which was available in 687 (90.8\%) out of $757 \mathrm{MET}+$ patients, in correlation to our outcome parameters NIHSS on admission, mRS after 3 months, mortality, and sICH. We found no significant association of MET dose (figure 4A). In addition, we assessed $\mathrm{HbAlc}$ levels as a measure of diabetes control between MET+ and MET- groups. Information on HbAlc levels was available in $1,223(63.7 \%)$ out of 1,919 patients. HbA1c levels were balanced after matching $(S M D=0.091$, figure 4B).

Figure 1 Flowchart of patients included in this study

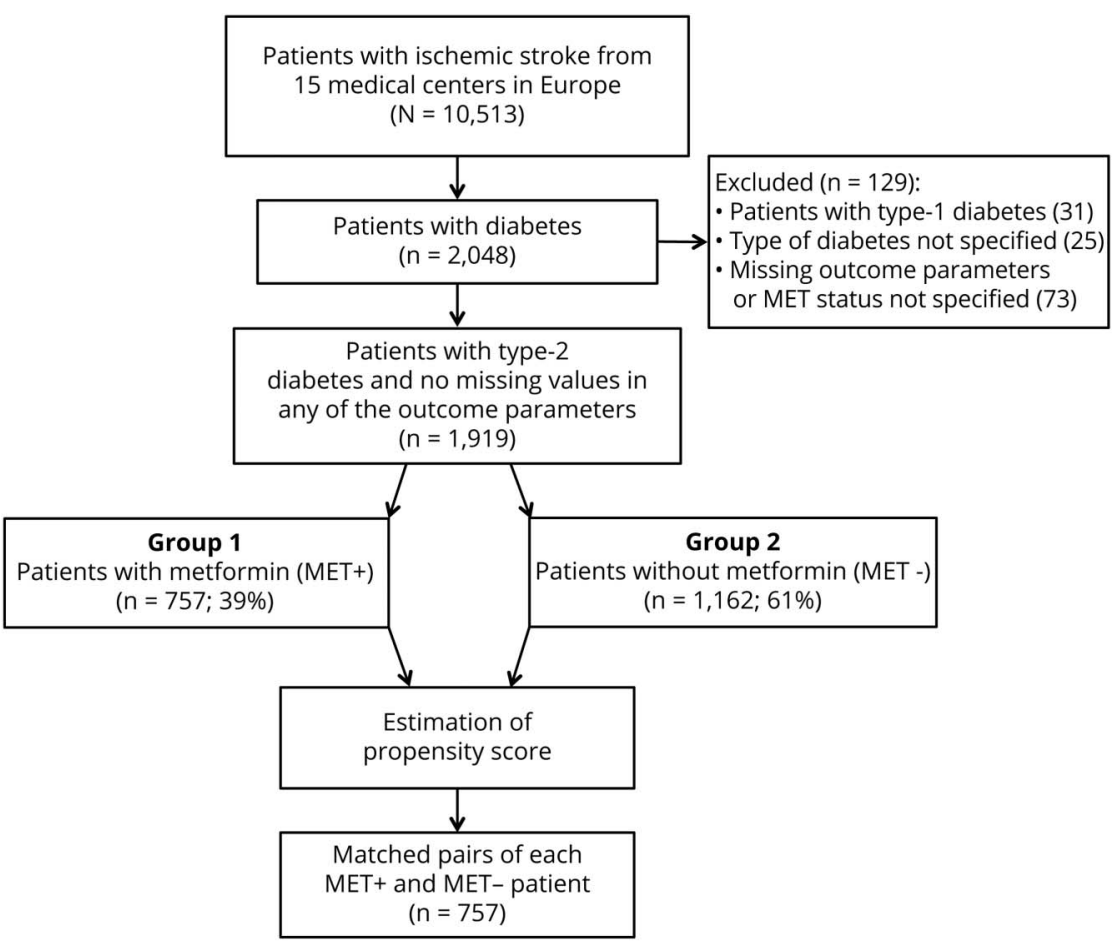


Table 1 Patient characteristics

\begin{tabular}{|c|c|c|c|c|c|c|}
\hline & \multicolumn{4}{|l|}{ At baseline } & \multicolumn{2}{|l|}{ After matching } \\
\hline & MET+ $(n=757)$ & MET $-(n=1,162)$ & $p$ Value $^{a}$ & SMD & MET $-(n=757)$ & SMD \\
\hline \multicolumn{7}{|l|}{ Demographic data } \\
\hline Age, y (SD) & $71.4(9.5)$ & $73.8(10.6)$ & $<0.001$ & 0.240 & $71.8(10.9)$ & 0.043 \\
\hline Female, n (\%) & $279(36.9)$ & $495(42.6)$ & 0.014 & 0.057 & $299(39.5)$ & 0.026 \\
\hline \multicolumn{7}{|l|}{ Risk factors, n (\%) } \\
\hline Hypertension & $673(88.9)$ & $1,008(86.7)$ & 0.184 & 0.022 & $656(86.7)$ & 0.022 \\
\hline Hypercholesterolemia & $480(63.6)$ & $619(53.6)$ & $<0.001$ & 0.100 & $448(59.3)$ & 0.042 \\
\hline CHD & $182(24.1)$ & $306(26.4)$ & 0.288 & 0.023 & $182(24.1)$ & $<0.001$ \\
\hline Atrial fibrillation & $175(23.3)$ & $420(36.4)$ & $<0.001$ & 0.131 & $186(24.8)$ & 0.015 \\
\hline Current smoking & $94(18.3)$ & $170(16.9)$ & 0.568 & 0.013 & $117(18.2)$ & 0.001 \\
\hline Prior stroke & $145(19.3)$ & $271(23.4)$ & 0.040 & 0.041 & $146(19.3)$ & 0.001 \\
\hline \multicolumn{7}{|l|}{ Prestroke medication, n (\%) } \\
\hline Antihypertensives & $497(79.6)$ & $541(70.1)$ & $<0.001$ & 0.096 & $404(76.2)$ & 0.034 \\
\hline Statins & $342(48.6)$ & $368(33.2)$ & $<0.001$ & 0.155 & $311(43.4)$ & 0.052 \\
\hline Antiplatelets & $421(56.1)$ & $556(48.3)$ & 0.001 & 0.078 & $404(53.9)$ & 0.022 \\
\hline Preanticoagulants & $42(5.6)$ & $80(7.0)$ & 0.272 & 0.014 & $47(6.3)$ & 0.007 \\
\hline \multicolumn{7}{|l|}{ Clinical measures, mean (SD) } \\
\hline Systolic blood pressure, $\mathrm{mmHg}$ & $159.3(25.0)$ & $158.7(25.3)$ & 0.619 & 0.024 & $158.7(25.9)$ & 0.023 \\
\hline Diastolic blood pressure, $\mathrm{mmHg}$ & $84.1(16.7)$ & $84.4(16.7)$ & 0.598 & 0.022 & $83.3(16.2)$ & 0.047 \\
\hline Glucose on admission, $\mathrm{mmol} / \mathrm{L}$ & $9.4(3.5)$ & $9.6(4.0)$ & 0.609 & 0.057 & $9.4(3.9)$ & 0.002 \\
\hline Creatinine on admission, $\mu \mathrm{mol} / \mathrm{L}$ & $87.1(47.7)$ & $102.0(63.0)$ & $<0.001$ & 0.267 & $90.6(46.6)$ & 0.075 \\
\hline Platelets on admission, $10^{9} / \mathrm{L}$ & $232.4(67.9)$ & $243.1(87.0)$ & 0.125 & 0.136 & $234.1(74.1)$ & 0.024 \\
\hline INR on admission & $1.0(0.2)$ & $1.1(0.1)$ & $<0.001$ & 0.165 & $1.0(0.1)$ & 0.089 \\
\hline Stroke-to-needle time, $\min$ & $161.8(98.5)$ & $158.0(105.8)$ & 0.525 & 0.037 & $158.4(120.5)$ & 0.030 \\
\hline Stroke etiology ${ }^{\mathbf{b}}(\%)$ & & & $<0.001$ & 0.071 & & 0.027 \\
\hline Cardioembolic & $248(33.4)$ & $503(43.9)$ & & & $272(36.4)$ & \\
\hline Large artery atherosclerosis & $227(30.6)$ & $269(23.5)$ & & & 209 (27.9) & \\
\hline Small artery occlusion & $78(10.5)$ & $74(6.5)$ & & & $61(8.2)$ & \\
\hline Other & $13(1.8)$ & $24(2.1)$ & & & $18(2.4)$ & \\
\hline Undetermined & $58(7.8)$ & $117(10.2)$ & & & $74(9.9)$ & \\
\hline$>1$ Etiology & $118(15.9)$ & $158(13.8)$ & & & $114(15.2)$ & \\
\hline
\end{tabular}

Abbreviations: $\mathrm{CHD}=$ coronary heart disease; INR = international normalized ratio; $\mathrm{MET}$ = metformin; SMD = absolute standardized mean difference. Clinical characteristics of patient groups with (MET+) or without (MET-) metformin treatment.

a Wilcoxon test for continuous variables reported as mean (SD) and $\chi^{2}$ test for categorical variables reported as frequencies (percentage of the available data).

${ }^{\text {b }}$ Stroke etiology was classified according to Trial of Org 10172 in Acute Stroke Treatment (TOAST) criteria. ${ }^{11}$

\section{Discussion}

This multicenter observational study revealed the following key findings: patients with diabetes pretreated with MET who had an acute ischemic stroke and received thrombolysis had less severe strokes on admission and better functional outcome at 3 months compared to those not pretreated with MET. In addition, patients pretreated with MET showed a lower mortality rate after receiving IVT. The effect remained stable after PSM for a large number of potential confounders. 
Table 2 Characteristics of patients at baseline after matching (imputed data set) ${ }^{\mathrm{a}}$

\begin{tabular}{|c|c|c|c|}
\hline & $\mathrm{MET}+(\mathrm{n}=757)$ & MET $-(n=757)$ & SMD \\
\hline \multicolumn{4}{|l|}{ Demographic data } \\
\hline Age, y (SD) & $71.4(9.5)$ & $71.8(10.9)$ & 0.043 \\
\hline Female & 279 (36.9) & $299(39.5)$ & 0.026 \\
\hline \multicolumn{4}{|l|}{ Risk factors, n (\%) } \\
\hline Hypertension & $673(88.9)$ & $656(86.7)$ & 0.022 \\
\hline Hypercholesterolemia & $481(63.5)$ & $450(59.4)$ & 0.041 \\
\hline CHD & $183(24.2)$ & $182(24.0)$ & 0.001 \\
\hline Atrial fibrillation & $176(23.2)$ & $187(24.7)$ & 0.015 \\
\hline Current smoking & $135(17.8)$ & $139(18.4)$ & 0.005 \\
\hline Prior stroke & 145 (19.2) & $147(19.4)$ & 0.003 \\
\hline \multicolumn{4}{|l|}{ Prestroke medication, n (\%) } \\
\hline Antihypertensives & $613(81.0)$ & $578(76.4)$ & 0.046 \\
\hline Statins & $359(47.4)$ & $325(42.9)$ & 0.045 \\
\hline Antiplatelets & $424(56.0)$ & $410(54.2)$ & 0.018 \\
\hline Preanticoagulants & $42(5.5)$ & $49(6.5)$ & 0.009 \\
\hline \multicolumn{4}{|l|}{ Clinical measures, mean (SD) } \\
\hline Systolic blood pressure, $\mathrm{mmHg}$ & $159.6(24.8)$ & $158.8(25.9)$ & 0.032 \\
\hline Diastolic blood pressure, $\mathrm{mmHg}$ & $84.1(16.8)$ & $83.2(16.2)$ & 0.055 \\
\hline Glucose on admission, $\mathrm{mmol} / \mathrm{L}$ & $9.4(3.5)$ & $9.4(3.9)$ & 0.007 \\
\hline Creatinine on admission, $\mu \mathrm{mol} / \mathrm{L}$ & $87.0(47.7)$ & $92.0(51.7)$ & 0.101 \\
\hline Platelets on admission, $10^{9} / \mathrm{L}$ & $232.5(71.3)$ & $238.3(79.8)$ & 0.077 \\
\hline INR on admission & $1.0(0.2)$ & $1.0(0.1)$ & 0.028 \\
\hline Stroke-to-needle time, $\min$ & $161.4(96.8)$ & $158.4(120.2)$ & 0.028 \\
\hline Stroke etiology ${ }^{\mathbf{b}}(\%)$ & & & 0.021 \\
\hline Cardioembolic & $254(33.6)$ & $274(36.2)$ & \\
\hline Large artery atherosclerosis & $229(30.3)$ & $213(28.1)$ & \\
\hline Small artery occlusion & $78(10.3)$ & $61(8.1)$ & \\
\hline Other & $13(1.7)$ & $18(2.4)$ & \\
\hline Undetermined & $62(8.2)$ & $74(9.8)$ & \\
\hline >1 Etiology & $121(16.0)$ & $177(15.5)$ & \\
\hline
\end{tabular}

Abbreviations: $\mathrm{CHD}$ = coronary heart disease; INR = international normalized ratio; $\mathrm{MET}$ = metformin; SMD = standardized mean difference.

Values are $n(\%)$ or mean (SD). Clinical characteristics of patient groups with (MET+) or without (MET-) metformin treatment.

a Propensity score matching with demonstration of one of the imputed data sets randomly chosen: $r=12$ (augmented), $m=73$ (within).

${ }^{\text {b }}$ Stroke etiology was classified according to Trial of Org 10172 in Acute Stroke Treatment (TOAST) criteria. ${ }^{11}$

One possible mechanism of MET-induced protection in stroke is chronic activation of AMPK, a major sensor of energy balance, in a nitrite oxide-dependent fashion. ${ }^{21}$ AMPK is highly expressed in neurons and activated under low cellular energy conditions, e.g., cerebral ischemia. ${ }^{22} \mathrm{Li}$ et al. ${ }^{22}$ investigated the effects of MET in experimental stroke and showed that acutely administered MET exacerbated stroke damage through enhanced AMPK activation leading to metabolic dysfunction with increased lactate levels. In contrast, chronic MET administration diminished stroke-induced lactate formation and reduced stroke-enhanced cerebral AMPK activation. Possibly, long-term activation of AMPK due to 
Figure 2 Balancing of baseline confounders, measured with standardized mean difference (SMD) before and after matching

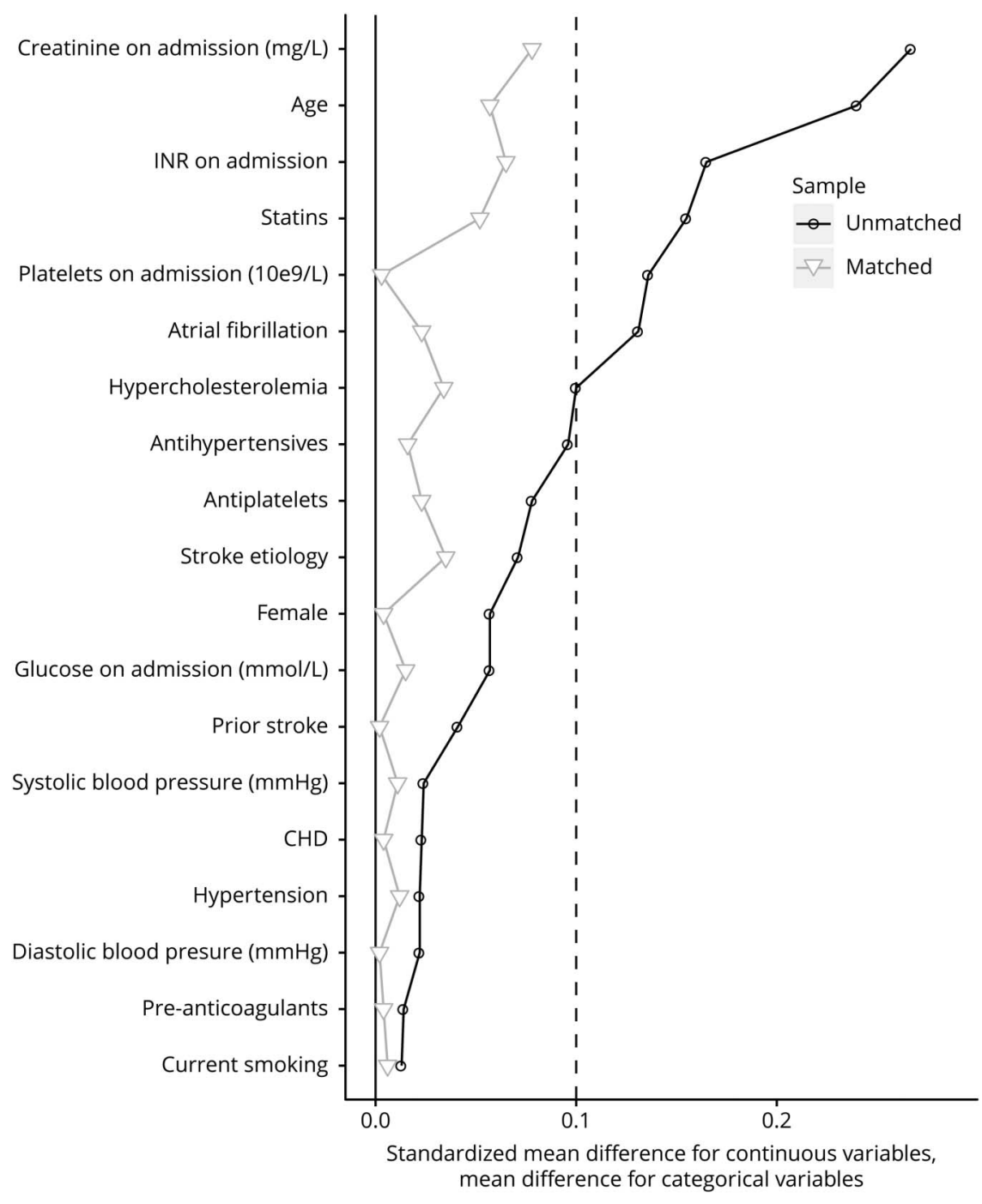

The variables were arranged in the order of decreasing SMD values before matching. CHD = coronary heart disease; INR = international normalized ratio.

chronic MET treatment might increase lactate levels in the intact brain as a sublethal (preconditioning) metabolic stress resulting in a tolerant state, thereby rendering the brain less vulnerable to subsequent injury. In case of stroke, patients pretreated with MET might therefore be more tolerant to ischemia, with fewer symptoms and better recovery. Strikingly, MET may exert its role in cardioprotection via similar mechanisms. Increased phosphorylation of AMPK and endothelial nitric oxide synthase and increase in PGC-1a expression in cardiomyocytes with a positive effect on mitochondrial structure leading to increased myocardial resistance to ischemiareperfusion injury have been demonstrated. ${ }^{23,24}$

Our results showing no statistically relevant difference between admission glucose levels of MET + compared to MET - patients ( $p=0.609$, table 1$)$ support the hypothesis of MET-related beneficial effects beyond glycemic control. This was further supported by well-balanced HbAlc levels between the MET+ and MET- groups (figure 4B). As a limitation, despite the large patient numbers, the character of a subgroup analysis with only 63.7\% available data for $\mathrm{HbA1c}$ levels has to be taken into account. In our cohort, we could not detect a dose-dependent effect of MET on any of the outcome measures (figure 4A), which suggests that the clinically relevant doses used for diabetes treatment are sufficient to exert the observed beneficial effect.

A recent Japanese study evaluated the effect of MET pretreatment on stroke severity and outcome in an Asian population of patients with stroke and diabetes and demonstrated that MET pretreatment was associated with milder neurologic signs and symptoms, but without significant benefit on functional outcome. ${ }^{25}$ The patient cohort examined by Mima et al. ${ }^{25}$ comprised a smaller collective with 355 patients, excluded prestroke impairment of activities of daily living ( $\mathrm{mRS}$ prior to onset $\geq 2$ ), and included less severe strokes (NIHSS on admission median of all patients 
Table 3 Comparison of outcome depending on MET treatment before and after matching

\begin{tabular}{|c|c|c|c|}
\hline Before matching & MET+ $(n=757)$ & MET- $(n=1,162)$ & $p$ Value \\
\hline \multicolumn{4}{|l|}{ Clinical scores } \\
\hline NIHSS on admission, mean (SD) & $10.0(6.7)$ & $11.7(6.5)$ & $<0.001$ \\
\hline mRS after 3 months, median [IQR] & $2(1.0-4.0)$ & $3(1.0-5.0)$ & $<0.001$ \\
\hline \multicolumn{4}{|l|}{ Complications, n (\%) } \\
\hline Symptomatic ICH (ECASS-II criteria) & $39(5.2)$ & $58(5.0)$ & 0.96 \\
\hline Mortality within 3 months, $n(\%)$ & $95(12.5)$ & $258(22.2)$ & $<0.001$ \\
\hline After matching & MET+ $(n=757)$ & MET - $(n=757)$ & $p$ Value \\
\hline \multicolumn{4}{|l|}{ Clinical scores } \\
\hline NIHSS on admission, mean (SD) & $10.0(6.7)$ & $11.3(6.5)$ & $<0.001$ \\
\hline mRS after 3 months, median [IQR] & $2(1.0-4.0)$ & $3(1.0-4.0)$ & $<0.001$ \\
\hline \multicolumn{4}{|l|}{ Complications, n (\%) } \\
\hline Symptomatic ICH (ECASS-II criteria) & $39(5.2)$ & $39(5.2)$ & 0.73 \\
\hline Mortality within 3 months, $\mathrm{n}(\%)$ & 95 (12.5) & $136(18)$ & 0.008 \\
\hline
\end{tabular}

2, MET users 1 , nonusers 2). Our study refined and extended this finding of a beneficial effect on stroke severity as we observed a significantly lower stroke severity among MET+ than among MET - patients with stroke, to be treated with IVT in our much larger $(\mathrm{n}=1919)$ thrombolysis cohort of many European Centers.
More importantly and as a novelty, we observed that functional outcome at 3 months was more favorable in MET+ than in MET - patients. Our results do not prove that treatment with IVT is more efficient or safe in patients pretreated with MET, as these patients showed less severe strokes on admission demonstrated by a lower NIHSS on admission

Figure 3 Bar plots of modified Rankin Scale (mRS) categories at 3 months

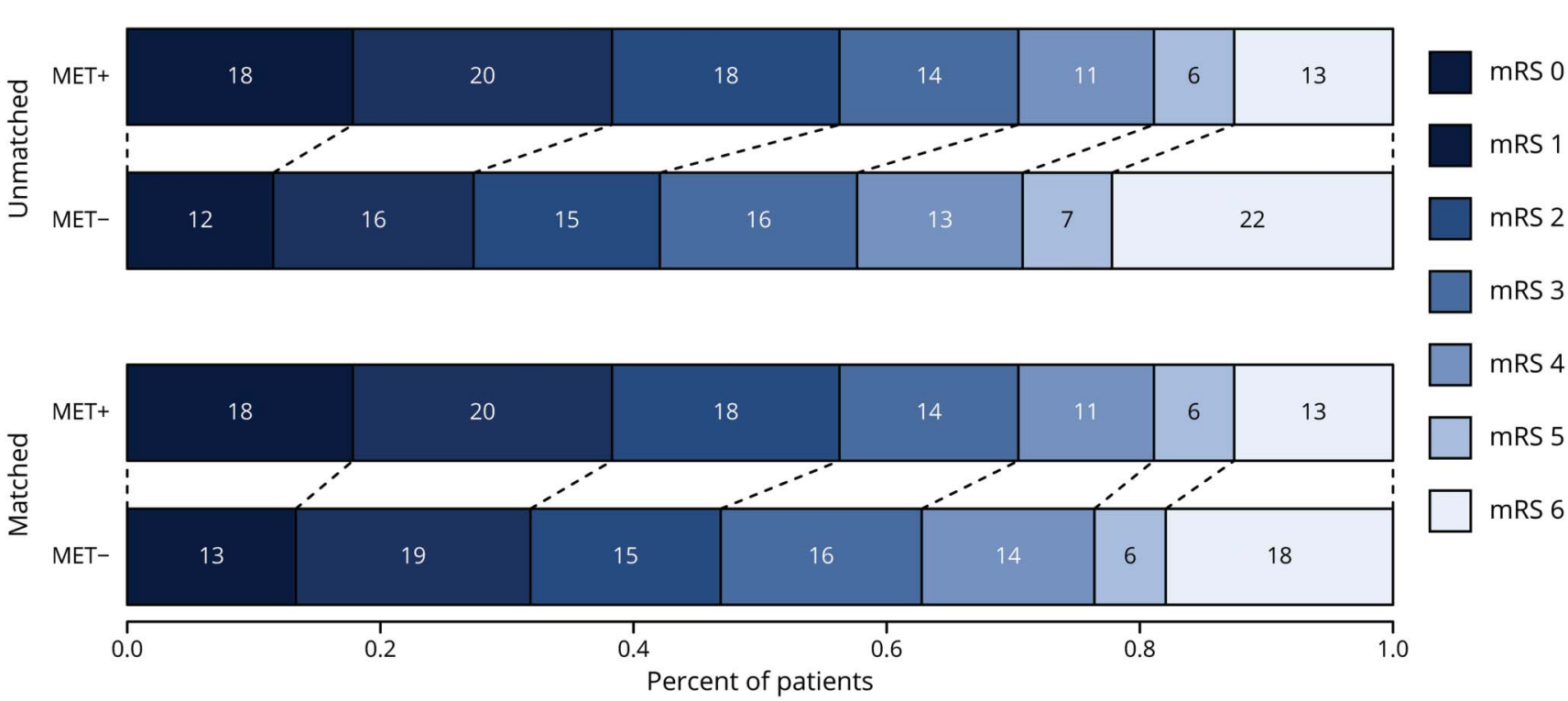

MET+ indicates the group of patients with metformin; MET- indicates the group of patients without metformin. Top panel: unmatched patients; bottom panel: matched pairs. 
A
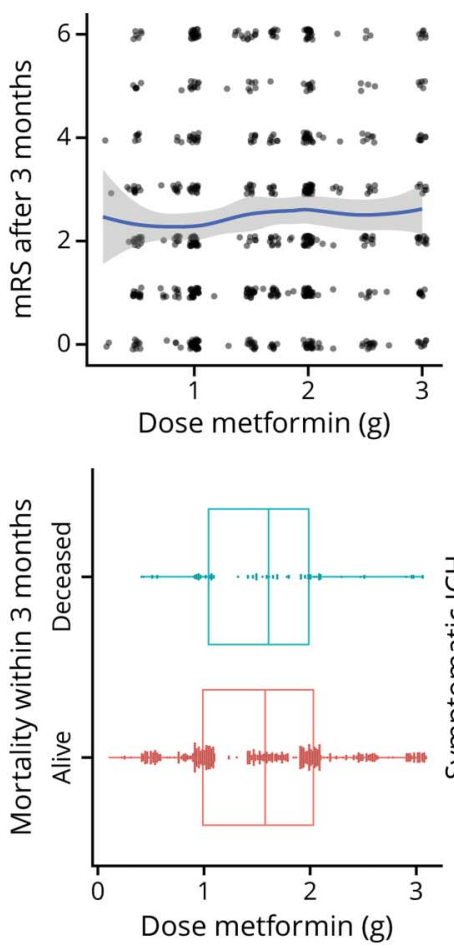

B
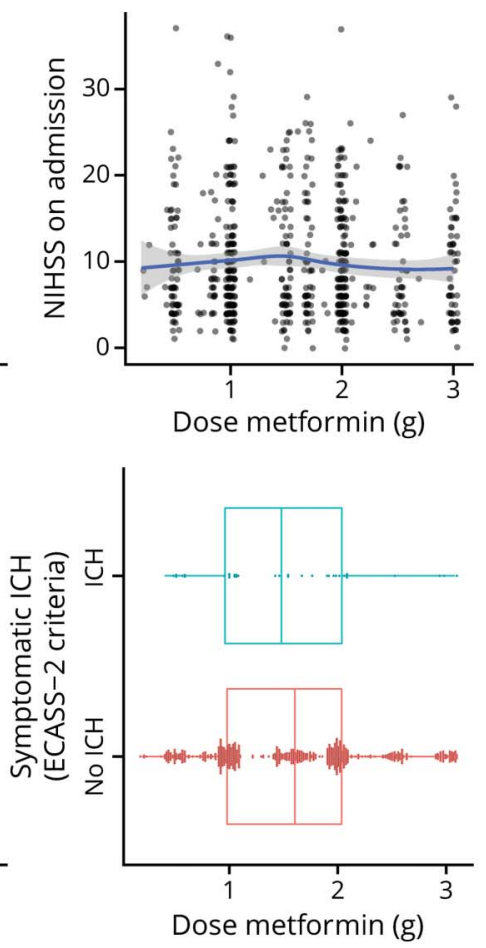

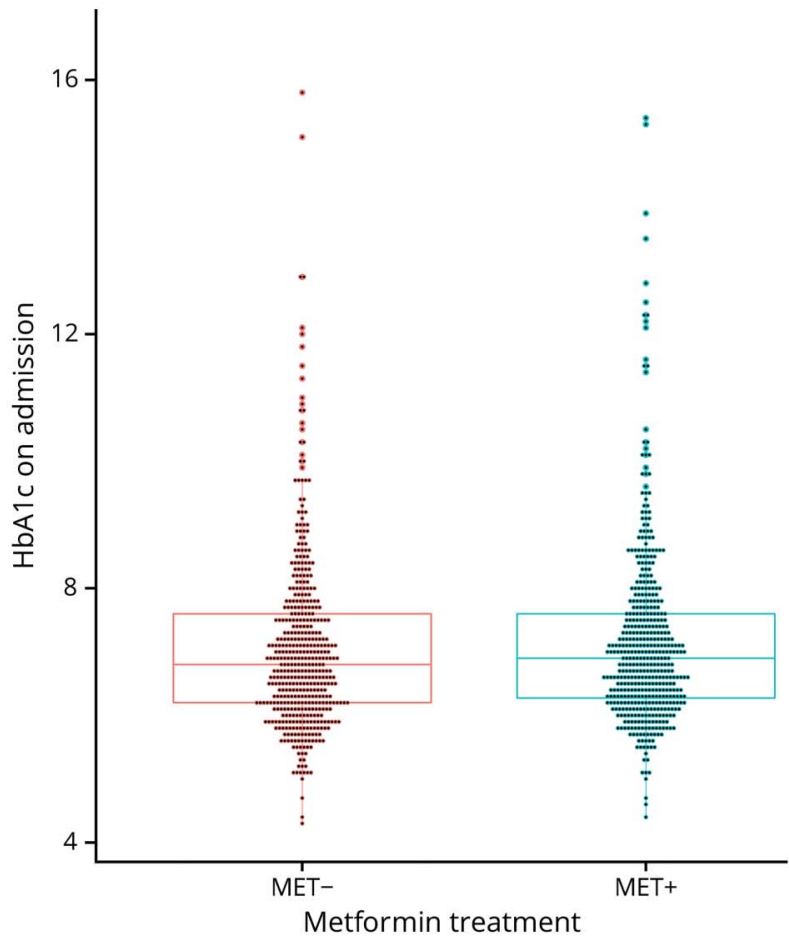

(A) MET dose in grams in correlation with NIH Stroke Scale (NIHSS) score on admission, modified Rankin Scale (mRS) score after 3 months, intracranial hemorrhage $(\mathrm{ICH})$, and mortality within 3 months after stroke onset. (B) Distribution of HbA1C values on admission in percent presented as medians with interquartile ranges (IQR) as a parameter of diabetes control in both cohorts of MET+ and MET- patients. ECASS-2 = European Cooperative Acute Stroke Study II.

compared to the non-pretreated (MET-) patient group. This suggests that MET exerts protection even before stroke onset and IVT. We therefore refrained from adjustment of groups for NIHSS on admission. Consequently, we can assume that at least part of the effect of MET on clinical outcome at 3 months is caused by the lower stroke severity on admission.

One limitation of the current multicenter registry study is its observational design with a certain risk of bias from heterogeneity of the different contributing centers about the use vs nonuse of MET. However, there is a standardized study approach concerning clinical and outcome measures, data collection, and analysis of all centers within the TRISP network, which has proven reliable and effective in previous studies. ${ }^{26,27}$ When adjusting for center-specific heterogeneity, the beneficial effect of MET was preserved. We cannot rule out that potentially unknown or unmeasured confounders such as duration of prestroke MET as well as poststroke or other antidiabetic medication may have introduced a bias and added to the favorable outcome in the MET+ group. For the clinical outcome scores, however, there is very strong evidence for between-group differences, and a potentially unmeasured confounder would need to be very strong to account for the favorable MET+ outcome, which is very unlikely considering correction for 19 well-known covariates. In future studies with prospective design, measures such as disease duration, time and dose of MET treatment, continuation after stroke, and poststroke medication should be taken into consideration to better characterize optimal treatment conditions for neuroprotection in stroke.

The present study emphasizes prophylactic protective effects of chronic MET intake in patients with stroke and diabetes resulting in less severe stroke, better functional outcome, and a lower mortality rate after IVT. Our data suggest that MET should be continued as a first line treatment for patients with diabetes, especially for patients with a high risk of stroke.

\section{Acknowledgment}

This study was supported by funds from the Swiss National Science Foundation, UZH Filling the Gap Foundation, and a research fund from Boehringer Ingelheim.

\section{Study funding}

No targeted funding reported.

\section{Disclosure}

L. Westphal, R. Widmer, U. Held, K. Steigmiller, C. Hametner, P. Ringleb, S. Curtze, N. Martinez-Majander, M. Tiainen, 
J. Scheitz, and H. Erdurn report no disclosures relevant to the manuscript. A. Polymeris has received research support from the Swiss Academy of Medical Sciences. C. Traenka has received a personal scholarship from the University of Basel, research support from the Swiss Heart Foundation and Swiss National Science Foundation, and a travel grant from Bayer. A. Eskandari, P. Michel, M. Heldner, and M. Arnold report no disclosures relevant to the manuscript. A. Zini received speaker fees and consulting fees from Boehringer-Ingelheim and Medtronic and serves on an advisory board from Boehringer-Ingelheim, Stryker, and Daiichi-Sankio. L. Vandelli, J. Coutinho, and A. Groot report no disclosures relevant to the manuscript. V. Padjen received travel or speaker honoraria from Boehringer Ingelheim and Pfizer and honoraria from scientific advisory board participation from Medtronic. D. Jovanovic received travel or speaker honoraria from Bayer, Pfizer, and Boehringer Ingelheim; and is a member of the scientific advisory board for Boehringer Ingelheim. Y. Bejot, C. Brenière, G. Turc, P. Seners, A. Pezzini, M. Magoni, D. Leys, S. Gilliot, and M. Scherrer report no disclosures relevant to the manuscript. G. Kägi received research funds from the Swiss National Foundation, the Swiss Heart Foundation, and the Swiss Parkinson Association and has advisory board memberships for Bayer and Zambon. A. Luft reports no disclosures relevant to the manuscript. H. Gensicke has received research support from the Swiss National Science Foundation. P. Nederkoorn reports no disclosures relevant to the manuscript. T. Tatlisumak has research contracts with Bayer, BoehringerIngelheim, Brains-Gate, Pfizer, and Portola and had advisory board memberships for Bayer, Boehringer-Ingelheim, BrainsGate, and Lumosa Pharmaceuticals. S. Engelter has received funding for travel or speaker honoraria from Bayer, Boehringer Ingelheim, and Daiichi-Sankyo; has served on scientific advisory boards for Bayer, Boehringer Ingelheim, BMS/Pfizer, and MindMaze and on the editorial board of Stroke; and has received an educational grant from Pfizer, compensation from Stago for educational efforts, research support from the Science Funds [Wissenschaftsfonds] of the University Hospital Basel, the University Basel, the "Freiwillige Akademische Gesellschaft Basel," the Swiss Heart Foundation, and the Swiss National Science Foundation. $S$. Wegener received research funds from the Swiss National Science Foundation, the UZH Filling the Gap Foundation, and Boehringer Ingelheim, and speakers honorarium from Amgen. C. Nolte received research support from DZHK (Deutsches Zentrum für Herz-Kreislauf-Forschung), DZNE (Deutsches Zentrum für neurodegenerative Erkrankungen), and $\mathrm{BIH}$ (Berlin Institute of Health), and honoraria or consultancies from BMS, Pfizer, Boehringer Ingelheim, Sanofi, and Gore \& Associates. Go to Neurology.org/N for full disclosures.

\section{Publication history}

Received by Neurology April 19, 2019. Accepted in final form January 6, 2020.

\section{Appendix 1 Authors}

\begin{tabular}{lll}
\hline Name & Location & Contribution \\
\hline $\begin{array}{l}\text { Laura P. } \\
\text { Westphal, }\end{array}$ & $\begin{array}{l}\text { Department of Neurology, } \\
\text { MD }\end{array}$ & $\begin{array}{l}\text { Contributed to data } \\
\text { Switzerland }\end{array}$ \\
& & $\begin{array}{l}\text { analysis and } \\
\text { interpretation, wrote the } \\
\text { first draft of the } \\
\text { manuscript, critically } \\
\text { revised the manuscript, } \\
\text { was involved in } \\
\text { acquisition of data, } \\
\text { approved the final version } \\
\text { of the manuscript }\end{array}$ \\
\end{tabular}

\begin{tabular}{lll}
\hline $\begin{array}{l}\text { Roni } \\
\text { Widmer, M } \\
\text { Med }\end{array}$ & $\begin{array}{l}\text { Department of Neurology, } \\
\text { University Hospital Zurich, } \\
\text { Switzerland }\end{array}$ & $\begin{array}{l}\text { Critically revised the } \\
\text { manuscript, was involved } \\
\text { in acquisition of data, } \\
\text { approved the final version } \\
\text { of the manuscript }\end{array}$ \\
\hline
\end{tabular}

\begin{tabular}{lll}
\hline Ulrike Held, & Epidemiology, Biostatistics & Performed the statistical \\
PhD & $\begin{array}{l}\text { and Prevention Institute, } \\
\text { Department of }\end{array}$ & $\begin{array}{l}\text { data analysis, critical } \\
\text { revision of the manuscript } \\
\text { Biostatistics, University of }\end{array}$ \\
& Zurich, Switzerland & \\
\end{tabular}

\begin{tabular}{|c|c|c|}
\hline $\begin{array}{l}\text { Klaus } \\
\text { Steigmiller, } \\
\text { BSc }\end{array}$ & $\begin{array}{l}\text { Epidemiology, Biostatistics } \\
\text { and Prevention Institute, } \\
\text { Department of } \\
\text { Biostatistics, University of } \\
\text { Zurich, Switzerland }\end{array}$ & $\begin{array}{l}\text { Performed the statistical } \\
\text { data analysis, critical } \\
\text { revision of the manuscript }\end{array}$ \\
\hline
\end{tabular}

\begin{tabular}{ll}
\hline Christian & Department of Neurology, \\
Hametner, & University Hospital \\
MD & Heidelberg, Germany
\end{tabular}

Critically revised the manuscript, was involved in acquisition of data, approved the final version of the manuscript

\begin{tabular}{lll}
\hline $\begin{array}{l}\text { Peter } \\
\text { Ringleb, MD }\end{array}$ & $\begin{array}{l}\text { Department of Neurology, } \\
\text { University Hospital } \\
\text { Heidelberg, Germany }\end{array}$ & $\begin{array}{l}\text { Critically revised the } \\
\text { manuscript, was involved } \\
\text { in acquisition of data, } \\
\text { approved the final version } \\
\text { of the manuscript }\end{array}$ \\
\end{tabular}

\begin{tabular}{|c|c|c|}
\hline $\begin{array}{l}\text { Sami Curtze, } \\
\text { MD, PhD }\end{array}$ & $\begin{array}{l}\text { Department of Neurology, } \\
\text { University of Helsinki and } \\
\text { Helsinki University } \\
\text { Hospital, Finland }\end{array}$ & $\begin{array}{l}\text { Critically revised the } \\
\text { manuscript, was involved } \\
\text { in acquisition of data, } \\
\text { approved the final version } \\
\text { of the manuscript }\end{array}$ \\
\hline
\end{tabular}

\begin{tabular}{lll}
\hline $\begin{array}{l}\text { Nicolas } \\
\text { Martinez- } \\
\text { Majander, } \\
\text { MD }\end{array}$ & $\begin{array}{l}\text { Department of Neurology, } \\
\text { University of Helsinki and } \\
\text { Helsinki University } \\
\text { Hospital, Finland }\end{array}$ & $\begin{array}{l}\text { Critically revised the } \\
\text { manuscript, was involved } \\
\text { in acquisition of data, } \\
\text { approved the final version } \\
\text { of the manuscript }\end{array}$ \\
\hline $\begin{array}{l}\text { Marjaana } \\
\text { Tiainen, MD }\end{array}$ & $\begin{array}{l}\text { Department of Neurology, } \\
\text { University of Helsinki and } \\
\text { Helsinki University } \\
\text { Hospital, Finland }\end{array}$ & $\begin{array}{l}\text { Critically revised the } \\
\text { manuscript, was involved } \\
\text { in acquisition of data, } \\
\text { approved the final version } \\
\text { of the manuscript }\end{array}$ \\
& & and
\end{tabular}

Christian H. Department of Neurology Critically revised the

$\begin{array}{lll}\text { Christian H. } & \text { Department of Neurology } & \text { Critically revised the } \\ \text { Nolte, MD } & \text { and Center for Stroke } & \text { manuscript, was involved }\end{array}$ Research, Charité in acquisition of data, University Hospital, Berlin, approved the final version Germany of the manuscript

\begin{tabular}{lll}
\hline Jan F. Scheitz, \\
MD & $\begin{array}{l}\text { Department of Neurology } \\
\text { and Center for Stroke } \\
\text { Research, Charite } \\
\text { University Hospital, Berlin, } \\
\text { Germany }\end{array}$ & $\begin{array}{l}\text { Critically revised the } \\
\text { manuscript, was involved } \\
\text { in acquisition of data, } \\
\text { approved the final version } \\
\text { of the manuscript }\end{array}$ \\
\hline $\begin{array}{l}\text { Hebun Erdur, } \\
\text { MD }\end{array}$ & $\begin{array}{l}\text { Department of Neurology } \\
\text { and Center for Stroke } \\
\text { Research, Charité } \\
\text { University Hospital, Berlin, } \\
\text { Germany }\end{array}$ & $\begin{array}{l}\text { Critically revised the } \\
\text { manuscript, was involved } \\
\text { in acquisition of data, } \\
\text { approved the final version } \\
\text { of the manuscript }\end{array}$ \\
\hline
\end{tabular}


Appendix 1 (continued)

\begin{tabular}{|c|c|c|}
\hline Name & Location & Contribution \\
\hline $\begin{array}{l}\text { Alexandros } \\
\text { A. Polymeris, } \\
\text { MD }\end{array}$ & $\begin{array}{l}\text { Stroke Center and } \\
\text { Neurology, University } \\
\text { Hospital Basel and } \\
\text { University Basel, } \\
\text { Switzerland }\end{array}$ & $\begin{array}{l}\text { Critically revised the } \\
\text { manuscript, was involved } \\
\text { in acquisition of data, } \\
\text { approved the final version } \\
\text { of the manuscript }\end{array}$ \\
\hline $\begin{array}{l}\text { Christopher } \\
\text { Traenka, MD }\end{array}$ & $\begin{array}{l}\text { Stroke Center and } \\
\text { Neurology, University } \\
\text { Hospital Basel and } \\
\text { University Basel, } \\
\text { Switzerland }\end{array}$ & $\begin{array}{l}\text { Critically revised the } \\
\text { manuscript, was involved } \\
\text { in acquisition of data, } \\
\text { approved the final version } \\
\text { of the manuscript }\end{array}$ \\
\hline $\begin{array}{l}\text { Ashraf } \\
\text { Eskandari, } \\
\text { RN }\end{array}$ & $\begin{array}{l}\text { Department of Neurology, } \\
\text { University Hospital } \\
\text { Lausanne, Switzerland }\end{array}$ & $\begin{array}{l}\text { Critically revised the } \\
\text { manuscript, was involved } \\
\text { in acquisition of data, } \\
\text { approved the final version } \\
\text { of the manuscript }\end{array}$ \\
\hline $\begin{array}{l}\text { Patrik } \\
\text { Michel, MD }\end{array}$ & $\begin{array}{l}\text { Department of Neurology, } \\
\text { University Hospital } \\
\text { Lausanne, Switzerland }\end{array}$ & $\begin{array}{l}\text { Critically revised the } \\
\text { manuscript, was involved } \\
\text { in acquisition of data, } \\
\text { approved the final version } \\
\text { of the manuscript }\end{array}$ \\
\hline $\begin{array}{l}\text { Mirjam R. } \\
\text { Heldner, MD }\end{array}$ & $\begin{array}{l}\text { Department of Neurology, } \\
\text { Inselspital, Bern University } \\
\text { Hospital, University of } \\
\text { Bern, Switzerland }\end{array}$ & $\begin{array}{l}\text { Critically revised the } \\
\text { manuscript, was involved } \\
\text { in acquisition of data, } \\
\text { approved the final version } \\
\text { of the manuscript }\end{array}$ \\
\hline $\begin{array}{l}\text { Marcel } \\
\text { Arnold, MD }\end{array}$ & $\begin{array}{l}\text { Department of Neurology, } \\
\text { Inselspital, Bern University } \\
\text { Hospital, University of } \\
\text { Bern, Switzerland }\end{array}$ & $\begin{array}{l}\text { Critically revised the } \\
\text { manuscript, was involved } \\
\text { in acquisition of data, } \\
\text { approved the final } \\
\text { version of the } \\
\text { manuscript }\end{array}$ \\
\hline $\begin{array}{l}\text { Andrea Zini, } \\
\text { MD }\end{array}$ & $\begin{array}{l}\text { IRCCS Istituto delle Scienze } \\
\text { Neurologiche di Bologna, } \\
\text { Department of Neurology } \\
\text { and Stroke Center, } \\
\text { Maggiore Hospital, } \\
\text { Bologna, Italy }\end{array}$ & $\begin{array}{l}\text { Critically revised the } \\
\text { manuscript, was involved } \\
\text { in acquisition of data, } \\
\text { approved the final version } \\
\text { of the manuscript }\end{array}$ \\
\hline $\begin{array}{l}\text { Laura } \\
\text { Vandelli, MD }\end{array}$ & $\begin{array}{l}\text { Stroke Unit, Department } \\
\text { of Neuroscience, } \\
\text { S'Agostino-Estense } \\
\text { Hospital, Modena } \\
\text { University Hospital, Italy }\end{array}$ & $\begin{array}{l}\text { Critically revised the } \\
\text { manuscript, was involved } \\
\text { in acquisition of data, } \\
\text { approved the final version } \\
\text { of the manuscript }\end{array}$ \\
\hline $\begin{array}{l}\text { Jonathan M. } \\
\text { Coutinho, } \\
\text { MD, PhD }\end{array}$ & $\begin{array}{l}\text { Department of Neurology, } \\
\text { Amsterdam University } \\
\text { Medical Centers (AUMC), } \\
\text { Location AMC, University } \\
\text { of Amsterdam, the } \\
\text { Netherlands }\end{array}$ & $\begin{array}{l}\text { Critically revised the } \\
\text { manuscript, was involved } \\
\text { in acquisition of data, } \\
\text { approved the final version } \\
\text { of the manuscript }\end{array}$ \\
\hline $\begin{array}{l}\text { Adrien E. } \\
\text { Groot, MD, } \\
\text { PhD }\end{array}$ & $\begin{array}{l}\text { Department of Neurology, } \\
\text { Amsterdam University } \\
\text { Medical Centers (AUMC), } \\
\text { Location AMC, University } \\
\text { of Amsterdam, the } \\
\text { Netherlands }\end{array}$ & $\begin{array}{l}\text { Critically revised the } \\
\text { manuscript, was involved } \\
\text { in acquisition of data, } \\
\text { approved the final version } \\
\text { of the manuscript }\end{array}$ \\
\hline $\begin{array}{l}\text { Visnja } \\
\text { Padjen, MD, } \\
\text { PhD }\end{array}$ & $\begin{array}{l}\text { Neurology Clinic Belgrade, } \\
\text { Clinical Centre of Serbia }\end{array}$ & $\begin{array}{l}\text { critically revised the } \\
\text { manuscript, was involved } \\
\text { in acquisition of data, } \\
\text { approved the final version } \\
\text { of the manuscript }\end{array}$ \\
\hline $\begin{array}{l}\text { Dejana R. } \\
\text { Jovanovic, } \\
\text { MD, PhD }\end{array}$ & $\begin{array}{l}\text { Neurology Clinic Belgrade, } \\
\text { Clinical Centre of Serbia }\end{array}$ & $\begin{array}{l}\text { Critically revised the } \\
\text { manuscript, was involved } \\
\text { in acquisition of data, } \\
\text { approved the final } \\
\text { version of the } \\
\text { manuscript }\end{array}$ \\
\hline
\end{tabular}

Appendix 1 (continued)

\begin{tabular}{|c|c|c|}
\hline Name & Location & Contribution \\
\hline $\begin{array}{l}\text { Yannick } \\
\text { Bejot, MD, } \\
\text { PhD }\end{array}$ & $\begin{array}{l}\text { Department of Neurology, } \\
\text { University Hospital of } \\
\text { Dijon, University of } \\
\text { Burgundy, France }\end{array}$ & $\begin{array}{l}\text { Critically revised } \\
\text { the manuscript, was } \\
\text { involved in acquisition of } \\
\text { data, approved the final } \\
\text { version of the } \\
\text { manuscript }\end{array}$ \\
\hline $\begin{array}{l}\text { Céline } \\
\text { Brenière, MD }\end{array}$ & $\begin{array}{l}\text { Department of Neurology, } \\
\text { University Hospital of } \\
\text { Dijon, University of } \\
\text { Burgundy, France }\end{array}$ & $\begin{array}{l}\text { Critically revised the } \\
\text { manuscript, was } \\
\text { involved in acquisition } \\
\text { of data, approved the } \\
\text { final version of the } \\
\text { manuscript }\end{array}$ \\
\hline $\begin{array}{l}\text { Guillaume } \\
\text { Turc, MD, } \\
\text { PhD }\end{array}$ & $\begin{array}{l}\text { Department of Neurology, } \\
\text { Sainte-Anne Hospital, } \\
\text { Paris, France }\end{array}$ & $\begin{array}{l}\text { Critically revised the } \\
\text { manuscript, was } \\
\text { involved in acquisition } \\
\text { of data, approved the } \\
\text { final version of the } \\
\text { manuscript }\end{array}$ \\
\hline $\begin{array}{l}\text { Pierre } \\
\text { Seners, MD, } \\
\text { PhD }\end{array}$ & $\begin{array}{l}\text { Department of Neurology, } \\
\text { Sainte-Anne Hospital, } \\
\text { Paris, France }\end{array}$ & $\begin{array}{l}\text { Critically revised } \\
\text { the manuscript, was } \\
\text { involved in acquisition } \\
\text { of data, approved the } \\
\text { final version of the } \\
\text { manuscript }\end{array}$ \\
\hline
\end{tabular}

Alessandro Department of Clinical and Critically revised the

Pezzini, MD Experimental Sciences, manuscript, was involved Neurology Clinic, in acquisition of data, University of Brescia, Italy approved the final version of the manuscript

\begin{tabular}{lll}
\hline $\begin{array}{l}\text { Mauro } \\
\text { Magoni, MD }\end{array}$ & Stroke Unit, ASST Spedali & Critically revised the \\
& Civili, Brescia, Italy & manuscript, was involved \\
& in acquisition of data, \\
& approved the final version \\
of the manuscript
\end{tabular}

\begin{tabular}{lll}
\hline Didier Leys, & Department of Neurology, \\
MD & $\begin{array}{l}\text { University Hospital of Lille, } \\
\text { France }\end{array}$ & $\begin{array}{l}\text { Critically revised the } \\
\text { manuscript, was involved } \\
\text { in acquisition of data, } \\
\text { approved the final version } \\
\text { of the manuscript }\end{array}$ \\
\end{tabular}

Sixtine Department of Neurology, Critically revised the

Gilliot, MD University Hospital of Lille, manuscript, was involved France in acquisition of data, approved the final version of the manuscript

\begin{tabular}{lll}
\hline Michael J. & Department of Neurology, & Critically revised the \\
Scherrer, MD & $\begin{array}{l}\text { St. Gallen Cantonal } \\
\text { Hospital, Switzerland }\end{array}$ & $\begin{array}{l}\text { manuscript, was involved } \\
\text { in acquisition of data, } \\
\text { approved the final version } \\
\text { of the manuscript }\end{array}$ \\
\end{tabular}

\section{Georg Kägi, Department of Neurology, Critically revised the} MD St. Gallen Cantonal manuscript, was involved Hospital, Switzerland in acquisition of data, approved the final version of the manuscript

\begin{tabular}{ll}
\hline Andreas R. & Department of Neurology, \\
Luft, MD & University Hospital Zurich, \\
& Switzerland
\end{tabular}

Critically revised the manuscript, was involved in acquisition of data, approved the final version of the manuscript

\begin{tabular}{lll}
\hline Henrik & Stroke Center and & Critically revised the \\
Gensicke, & Neurology, University & manuscript, was involved \\
MD & Hospital Basel and & in acquisition of data, \\
University Basel, & approved the final version \\
& of the manuscript
\end{tabular}


Appendix 1 (continued)

\begin{tabular}{|c|c|c|}
\hline Name & Location & Contribution \\
\hline $\begin{array}{l}\text { Paul } \\
\text { Nederkoorn, } \\
\text { MD, PhD }\end{array}$ & $\begin{array}{l}\text { Department of Neurology, } \\
\text { Amsterdam University } \\
\text { Medical Centers (AUMC), } \\
\text { Location AMC, University } \\
\text { of Amsterdam, the } \\
\text { Netherlands }\end{array}$ & $\begin{array}{l}\text { Critically revised the } \\
\text { manuscript, was involved } \\
\text { in acquisition of data, } \\
\text { approved the final version } \\
\text { of the manuscript }\end{array}$ \\
\hline $\begin{array}{l}\text { Turgut } \\
\text { Tatlisumak, } \\
\text { MD, PhD }\end{array}$ & $\begin{array}{l}\text { Department of Neurology, } \\
\text { Sahlgrenska University } \\
\text { Hospital, and Department } \\
\text { of Clinical Neurosciences, } \\
\text { Institute of Neuroscience } \\
\text { and Physiology, } \\
\text { Sahlgrenska Academy at } \\
\text { University of Gothenburg, } \\
\text { Sweden }\end{array}$ & $\begin{array}{l}\text { Critically revised the } \\
\text { manuscript, was involved } \\
\text { in acquisition of data, } \\
\text { approved the final version } \\
\text { of the manuscript }\end{array}$ \\
\hline $\begin{array}{l}\text { Stefan T. } \\
\text { Engelter, MD }\end{array}$ & $\begin{array}{l}\text { Stroke Center and } \\
\text { Neurology, University } \\
\text { Hospital Basel and } \\
\text { University Basel; } \\
\text { Neurorehabilitation Unit, } \\
\text { University Center for } \\
\text { Medicine of Aging and } \\
\text { Rehabilitation Basel, Felix } \\
\text { Platter Hospital, University } \\
\text { of Basel, Switzerland }\end{array}$ & $\begin{array}{l}\text { Was involved in study } \\
\text { design, data } \\
\text { interpretation, critically } \\
\text { revised the manuscript, } \\
\text { was involved in acquisition } \\
\text { of data, approved the final } \\
\text { version of the manuscript }\end{array}$ \\
\hline $\begin{array}{l}\text { Susanne } \\
\text { Wegener, MD }\end{array}$ & $\begin{array}{l}\text { Department of Neurology, } \\
\text { University Hospital Zurich, } \\
\text { Switzerland }\end{array}$ & $\begin{array}{l}\text { Conceived and designed } \\
\text { the study and interpreted } \\
\text { the study data, critically } \\
\text { revised the manuscript, } \\
\text { was involved in acquisition } \\
\text { of data, approved the final } \\
\text { version of the manuscript }\end{array}$ \\
\hline
\end{tabular}

\section{Appendix 2 Coinvestigators}

Coinvestigators are listed at links.Iww.com/WNL/B149

\section{References}

1. Desilles JP, Meseguer E, Labreuche J, et al. Diabetes mellitus, admission glucose, and outcomes after stroke thrombolysis: a registry and systematic review. Stroke $2013 ; 44$ : 1915-1923.

2. Hacke W, Kaste M, Bluhmki E, et al. Thrombolysis with alteplase 3 to 4.5 hours after acute ischemic stroke. N Engl J Med 2008;359:1317-1329.
3. Chen R, Ovbiagele B, Feng W. Diabetes and stroke: epidemiology, pathophysiology, pharmaceuticals and outcomes. Am J Med Sci 2016;351:380-386.

4. Bailey CJ. The current drug treatment landscape for diabetes and perspectives for the future. Clin Pharmacol Ther 2015;98:170-184.

5. Triggle CR, Ding H. Cardiovascular impact of drugs used in the treatment of diabetes. Ther Adv Chronic Dis 2014;5:245-268.

6. Bailey CJ. Metformin: historical overview. Diabetologia 2017;60:1566-1576.

7. Jia J, Cheng J, Ni J, Zhen X. Neuropharmacological actions of metformin in stroke. Curr Neuropharmacol 2015;13:389-394.

8. Scheitz JF, Gensicke H, Zinkstok SM, et al. Cohort profile: thrombolysis in ischemic stroke patients (TRISP): a multicentre research collaboration. BMJ Open 2018;8: e023265.

9. Ringelstein EB, Chamorro A, Kaste M, et al. European Stroke Organisation recommendations to establish a stroke unit and stroke center. Stroke 2013;44:828-840.

10. Engelter ST, Soinne L, Ringleb P, et al. IV thrombolysis and statins. Neurology 2011; $77: 888-895$.

11. Gensicke H, Al Sultan AS, Strbian D, et al. Intravenous thrombolysis and platelet count. Neurology 2018;90:e690-e697.

12. Gillett MJ. International Expert Committee report on the role of the A1c assay in the diagnosis of diabetes. Diabetes Care 2009;32:1327-1334.

13. American Diabetes Association. Diagnosis and classification of diabetes mellitus. Diabetes Care 2010;33(suppl 1):S62-S69.

14. Adams HP Jr, Bendixen BH, Kappelle LJ, et al. Classification of subtype of acute ischemic stroke: definitions for use in a multicenter clinical trial: TOAST: Trial of Org 10172 in Acute Stroke Treatment. Stroke 1993;24:35-41.

15. Hacke W, Kaste M, Fieschi C, et al. Randomised double-blind placebo-controlled trial of thrombolytic therapy with intravenous alteplase in acute ischaemic stroke (ECASS II): Second European-Australasian Acute Stroke Study Investigators. Lancet 1998; 352:1245-1251

16. Mitra R, Reiter JP. A comparison of two methods of estimating propensity scores after multiple imputation. Stat Methods Med Res 2016;25:188-204.

17. Austin PC. An introduction to propensity score methods for reducing the effects of confounding in observational studies. Multivariate Behav Res 2011;46: 399-424.

18. Pratt JH. The role of surgery in the treatment of infertility. Trans N Engl Obstet Gynecol Soc 1959;13:77-92.

19. Licht C. New methods for generating significance levels from multiply-imputed data [dissertation]. Bamberg: Otto-Friedrich-Universitat Bamberg; 2010.

20. von Elm E, Altman DG, Egger M, et al. Strengthening the Reporting of Observational Studies in Epidemiology (STROBE) statement: guidelines for reporting observational studies. BMJ 2007;335:806-808.

21. Zou MH, Kirkpatrick SS, Davis BJ, et al. Activation of the AMP-activated protein kinase by the anti-diabetic drug metformin in vivo: role of mitochondrial reactive nitrogen species. J Biol Chem 2004;279:43940-43951.

22. Li J, Benashski SE, Venna VR, McCullough LD. Effects of metformin in experimental stroke. Stroke 2010;41:2645-2652.

23. Whittington HJ, Hall AR, McLaughlin CP, Hausenloy DJ, Yellon DM, Mocanu MM Chronic metformin associated cardioprotection against infarction: not just a glucose lowering phenomenon. Cardiovasc Drugs Ther 2013;27:5-16.

24. Varjabedian L, Bourji M, Pourafkari L, Nader ND. Cardioprotection by metformin: beneficial effects beyond glucose reduction. Am J Cardiovasc Drugs 2018;18: 181-193.

25. Mima Y, Kuwashiro T, Yasaka M, et al. Impact of metformin on the severity and outcomes of acute ischemic stroke in patients with type 2 diabetes mellitus. J Stroke Cerebrovasc Dis 2016;25:436-446.

26. Gensicke H, Frih AA, Strbian D, et al. Prognostic significance of proteinuria in stroke patients treated with intravenous thrombolysis. Eur J Neurol 2017;24:262-269.

27. Spaander FH, Zinkstok SM, Baharoglu IM, et al. Sex differences and functional outcome after intravenous thrombolysis. Stroke 2017;48:699-703. 


\section{Neurology}

Association of prestroke metformin use, stroke severity, and thrombolysis outcome Laura P. Westphal, Roni Widmer, Ulrike Held, et al.

Neurology 2020;95;e362-e373 Published Online before print June 29, 2020

DOI 10.1212/WNL.0000000000009951

This information is current as of June 29, 2020

\section{Updated Information \&} Services

References

Subspecialty Collections

Permissions \& Licensing

Reprints including high resolution figures, can be found at: http://n.neurology.org/content/95/4/e362.full

This article cites 26 articles, 12 of which you can access for free at: http://n.neurology.org/content/95/4/e362.full\#ref-list-1

This article, along with others on similar topics, appears in the following collection(s):

All Cerebrovascular disease/Stroke

http://n.neurology.org/cgi/collection/all_cerebrovascular_disease_strok e

Information about reproducing this article in parts (figures,tables) or in its entirety can be found online at:

http://www.neurology.org/about/about_the_journal\#permissions

Information about ordering reprints can be found online:

http://n.neurology.org/subscribers/advertise

Neurology ${ }^{\circledR}$ is the official journal of the American Academy of Neurology. Published continuously since 1951, it is now a weekly with 48 issues per year. Copyright () 2020 American Academy of Neurology. All rights reserved. Print ISSN: 0028-3878. Online ISSN: 1526-632X.

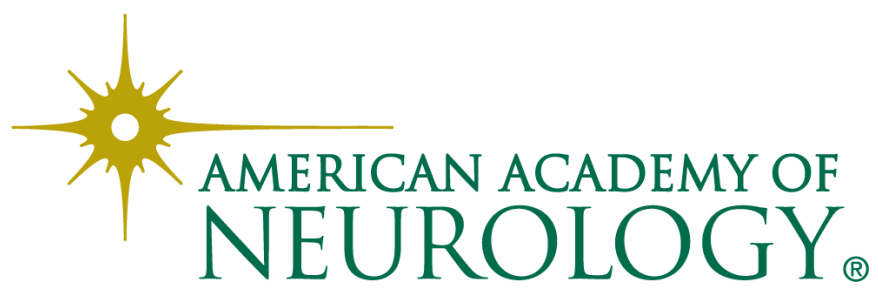

